\title{
A research on obesity among Turkish seafarers
}

\section{Selçuk Nas, Remzi Fışkın}

Maritime Faculty, Dokuz Eylul University, İzmir, Turkey

\begin{abstract}
Background: Obesity and overweight threaten not only seafarer's health but also the safety of operations on board a ship. The aim of the study was to investigate the statistical distribution of obesity and overweight among Turkish seafarers by using the health examination reports data collected between 2009 and 2012. Materials and methods: The data on weight, height and age obtained from 143,341 medical examination reports of Turkish seafarers were used with the official permission of Directorate General of Health for Border and Coastal Areas. Considering the data in the health reports, body mass index (BMI) values were calculated, analysed and compared with Turkish general population and Danish seafarers.

Results: It has been found that BMI values of Turkish seafarers were boomed over the years. While Turkish male seafarers get older, their BMI values rise progressively. After the age of $28, B M I$ scores exceed the acceptable level. In addition, they reach maximum average $27.8 \mathrm{BMI}$ value in their 50s.

Conclusions: The activities, which will provide awareness to Turkish seafarers and the ship operators about the dangers of obesity, should be done. Also convenient environments and time for physical exercise on board a ship must be provided for seafarers.
\end{abstract}

(Int Marit Health 2014; 65, 4: 187-191)

\section{Key words: obesity, body mass index, Turkish seafarers}

\section{INTRODUCTION}

In many parts of the world, obesity and overweight has become a major health problem. As a result of being obese and overweight, at least 2.8 million adults die each year [1]. The main impact of obesity on health is cardiovascular disorders [2].

The definitions of obesity and overweight are similar in general terms. According to World Health Organisation (WHO), obesity and overweight is defined as abnormal and excessive fat accumulation that presents a risk to health [3]. Health and Social Care Foundation (Turkey) defines obesity as the increase of body fat $[4,5]$.

The review of literature reports on obesity showed that obesity is a very important risk factor for some types of diseases, but it is considered as modifiable risk factor [6-10]. Besides its influence on health, overweight and obesity might pose a safety problem on board at sea. It might be difficult for overweight people to carry out safety tasks abroad in emergencies, to make use of escape routes and ladders and to step in a lifeboat or a life raft. This is significant issue not only for the overweight people but also for those being subject to their actions or engaged in assisting them [11]. In this context, the study made by Roberts et al. [12] shows that fatal accident and injury rates in shipping industry are higher than in construction industry and manufacturing industry. This shows that, due to the more risky working condition, seafarers are required to be fit in order to withstand risky situations. On the other hand, other study made by Bridger and Bennett [13] indicates that body mass index (BMI) and age has been associated with work ability and effect of high BMI on work ability is stronger.

A WHO report "Consultation an Obesity" published in 1997 [14] for the first time presented consistent system for classifying overweight and obesity. Then, it has been adopted internationally [15]. The consistent system was designated as BMI. The weight in kilograms divided by the 
Table 1. Classification of overweight according to body mass index (BMI) [Resource: WHO, 1997: 9]

\begin{tabular}{lll}
\hline Classification & BMI & Risk of co-morbidities \\
\hline Underweight & $<18.5$ & Low \\
Normal range & $18.5-24.9$ & Average \\
Overweight & $25-29.9$ & Increased \\
Obesity class I & $30.0-34.9$ & Moderate \\
Obesity class II & $35.0-39.9$ & Severe \\
Obesity class III & $\geq 40.0$ & Very severe
\end{tabular}

square of the height in meters brings out BMI. The relevant formula is shown below.

$$
\mathrm{BMI}=\frac{\text { Weight }}{{\text { (Height })^{2}}^{2}}
$$

The WHO classification of overweight and obesity, according to BMI, is shown in Table 1.

In Turkey, the most reliable and recent obesity research was carried out by Turkish Statistical Institute (TSI) [16]. In this research, 14,400 houses were screened for general health status, chronic diseases, height and weight of the Turkish people aged 15 years and over. Considering the result of the TSI [16] study, 39\% of men in Turkish population were overweight and 14\% were obese, as shown in the Table 2.

When reviewing the literature, a few studies related to obesity among seafarers were spotted. One of them was about life style, nutritional status and working conditions of Danish sailors [17]. The main objectives of the study were to reveal nutritional status and working conditions of Danish sailors. 390 sailors participated in the survey. The results of the study revealed that $22 \%$ of Danish sailors between 55 and 64 years of age were obese. The other study was about obesity among Danish seafarers [11]. The objectives of the study were to investigate the prevalence of overweight among male seafarers and to determine the potential consequences of adopting maximum allowable BMl for seafarers. Among 1,257 male Danish seafarers, 1\% between 45 and 66 years of age had weight below normal, $23 \%$ had normal weight and $77 \%$ had weight above normal, while $31 \%$ of this age group were obese. Another study related to obesity and nutritional status was about extent of the problem of overweight among Danish fishermen and seafarers [18]. According to this study, $33 \%$ of Danish seafarers between
45 and 64 years of age were obese. It has been found, based on body mass indices between studies surveyed in 1994, 2005 and 2011, that there was a statistically significant increase in the number of overweight and obese merchant seafarers over the years.

Obesity problem in Turkish maritime education was examined for the first time by Nas and ve Oksayan [19]. The study was carried out on students of Dokuz Eylul University Maritime Faculty. In this study, it has been found that students' weight and height has increased during 5-year undergraduate education. The BMI value of the students increased by $1.83 \mathrm{BMI}$ units in 5-year education period. At the time of graduation average BMI reached the value of 24.3. There are weight and height requirements for admission to maritime schools in Turkey. Dokuz Eylul University, Maritime Faculty, İzmir was the first to regulate the admission requirements according to $\mathrm{BMI}$ in 2013. The faculty identified 19-30 BMI range as a condition of accepting students [20].

On the other hand, in Turkey there is not any study that examined obesity and overweight among Turkish seafarers. For this reason, the aim of this study has been determined as to specify the prevalence of overweight and obesity among Turkish seafarers. Other objectives of the study are to reveal the height, weight and BMI values of Turkish male seafarers and compare BMI values of Turkish seafarers with that of Turkish general population and Danish seafarers.

\section{MATERIALS AND METHODS}

The study is based on measurements made as a part of medical examination that should be taken every 2 years by Turkish seafarers. The medical examination reports contain data on seafarers' age, height, and weight. The data officially requested are recorded on to Republic of Turkey Ministry of Health Directorate General of Health for Border and Coastal Areas' information management system. In this study, the medical data, obtained from 143,341 medical examination reports of Turkish seafarers were analysed. The data obtained were analysed by statistical program SPSS.20. Due to the fact that medical examination is conducted and renewed every 2 years; the data include more than one measurement data that belong to the same seafarers. Similar to this study, medical examination reports obtained by U.K. Atomic Energy Authority were also analysed by Howell [21] to reveal height, weight and BMI values of employees

Table 2. Distribution of body mass index (BMI) by gender in Turkish population [Resource: TSI, 2013]

\begin{tabular}{lllll} 
Turkish people & BMI < 18.5 & BMI 18.5-25.0 & BMI 25-30 & BMI $\geq \mathbf{3 0}$ \\
\cline { 2 - 5 } Age $\geq \mathbf{1 5}$ & Underweight & Normal weight & Overweight & Obese \\
\hline Male & $2.7 \%$ & $44.7 \%$ & $39.0 \%$ & $3.7 \%$ \\
Female & $5.1 \%$ & $43.6 \%$ & $30.4 \%$ & $20.9 \%$ \\
All & $3.9 \%$ & $44.2 \%$ & $34.8 \%$ & $17.2 \%$
\end{tabular}


working in this industry. This study provided us with some insight into the problem of obesity among seafarers.

\section{RESULTS}

In this study, data of 143,341 medical examination reports were analysed. The distribution of the reports and the gender of seafarers by years are shown in Table 3. Rate of woman seafarers among the Turkish seafarers is only 3\%. As shown in Table 3, each year approximately 35,000 seamen have received a medical examination report and the data was obtained from this reports.

When obtained data concerning age, weight, height and $\mathrm{BMI}$ values were analysed according to gender, statistically significant $(p<0.000)$ differences were detected. The average age of women seafarers was 26.79 , while that of men was 33.31; the average body weight of women seafarers was $61.01 \mathrm{~kg}$, while that of men was $77.48 \mathrm{~kg}$; the average height of women was $165.6 \mathrm{~cm}$, while that of men was $174.4 \mathrm{~cm}$. BMl of women was 22.16 , while that of men was 25.34 .

In order to compare these data with former studies on seafarers relevant to the subject, the BMI classification of Hoeyer and Hansen [11] was adopted as a reference, instead of WHO classification. Also, analysed data were collocated by considering the study of Hansen et al. [18], due to more recent data. In addition, only male seafarers were included in the analysis to make a comparison with related study. Classification of Hoeyer and Hansen [11] is stated below:

$$
\begin{aligned}
& \mathrm{BMI}<20.0 \text { : Below normal weight } \\
& 20.0 \leq \mathrm{BMI}<25.0 \text { : Normal weight } \\
& 25.0 \leq \mathrm{BMI}<30.0 \text { : Moderate overweight } \\
& \mathrm{BMI} \geq 30.0 \text { : Obesity }
\end{aligned}
$$

The comparisons of the results of this study with former studies on seafarers are shown in Table 4. Turkish male seafarers were divided into following age groups: 16-24, $25-44$ and $45-66$ years. As a result, 23\% of Turkish male seafarers in 16-24 age group, $44 \%$ of Turkish male seafarers in 25-44 age group and $52 \%$ of Turkish male seafarers in 45-66 age group were found to be overweight. The rate of
Table 3. Distribution of the number of seafarer by year and gender

\begin{tabular}{llll}
\hline \multirow{2}{*}{ Years } & \multicolumn{2}{l}{ Gender of seafarers } & Total \\
\cline { 2 - 3 } & Male & Female & \\
\hline 2009 & 31,602 & 956 & 32,558 \\
2010 & 34,770 & 868 & 35,638 \\
2011 & 36,392 & 1,051 & 37,443 \\
2012 & 36,566 & 1,136 & 37,702 \\
Total & 139,330 & 4,011 & 143,341
\end{tabular}

obesity among Turkish male seafarers in 45-66 age group was determined as $23 \%$.

The study has investigated whether there is significant difference between height, weight and BMI values of Turkish male seafarers by years and whether there is significant relationship between these BMI values and years. For this purpose, correlation and analysis of variance (ANOVA) tests were performed. According to analysis results, the average weight and average ages of Turkish male seafarers were correlated $(r=0.028, p \leq 0.000)$. Moreover, the average height values and average ages of Turkish male seafarers were correlated $(r=0.025, p \leq 0.000)$. Also, it has been found that the BMI values and averages ages of Turkish male seafarers were correlated $(r=0.017, p \leq 0.000)$.

According to the results of the ANOVA tests, the average values of height, weight and BMI by years are shown in Table 5.

According to the results of the ANOVA tests, the average values of height, weight and BMI by years are shown in Table 5 . The results of ANOVA revealed that there is significant difference between the years of health examination reports and average weight values $(F(3-139006)=38.303, p \leq 0.000)$. Moreover, there is significant difference between average values of $\mathrm{BMI}$ and the years of health examination reports $(F(3-138606)=17.201, p \leq 0.000)$. The study has investigated whether there is significant relationship between age of Turkish male seafarers and average weight and BMI values. The regression analysis diagram of average BMI and ages values is shown in Figure 1.

Table 4. Distribution of male Turkish seafarers according to age and body mass index (BMI) groups [*TUIK, 2012]

\begin{tabular}{lllll}
\hline $\begin{array}{l}\text { Turkish male seafarers } \\
(\mathbf{n = 1 3 1 , 1 5 2 )}\end{array}$ & BMI < 25.0 & BMI 25-30 & BMI $\geq \mathbf{3 0}$ & Number of participants \\
\hline 16-24 age group & $74.1 \%$ & $22.5 \%$ & $3.4 \%$ & 34,421 \\
$25-44$ age group & $44.1 \%$ & $43.3 \%$ & $12.6 \%$ & 68,038 \\
45-66 age group & $25.6 \%$ & $51.1 \%$ & $23.4 \%$ & 28,693 \\
All Turkish male seafarers & $47.9 \%$ & $39.6 \%$ & $12.5 \%$ & 131,152 \\
Turkish male population* & $47.3 \%$ & $39.0 \%$ & $13.7 \%$ & -
\end{tabular}


Table 5. The analysis of variance (ANOVA) results of the Turkish male seafarers' average height, weight and body mass index (BMI) values by years

\begin{tabular}{|c|c|c|c|c|c|c|c|c|c|}
\hline \multirow[t]{2}{*}{ Year } & \multicolumn{3}{|c|}{ Weight [kg] } & \multicolumn{3}{|c|}{ Height [cm] } & \multicolumn{3}{|l|}{ BMI } \\
\hline & Mean & SD & $\mathbf{N}$ & Mean & SD & $\mathbf{N}$ & Mean & SD & $\mathbf{N}$ \\
\hline 2009 & 77.02 & 12.9516 & 31,524 & 174.49 & 6.9123 & 31,431 & 25.269 & 3.8978 & 31,386 \\
\hline 2010 & 77.16 & 13.1900 & 34,687 & 174.64 & 6.9467 & 34,625 & 25.264 & 3.9468 & 34,545 \\
\hline 2011 & 77.76 & 13.5081 & 36,307 & 174.75 & 6.9259 & 36,315 & 25.421 & 4.0222 & 36,236 \\
\hline 2012 & 77.93 & 13.5684 & 36,492 & 174.97 & 6.8806 & 36,514 & 25.418 & 4.0307 & 36,443 \\
\hline
\end{tabular}

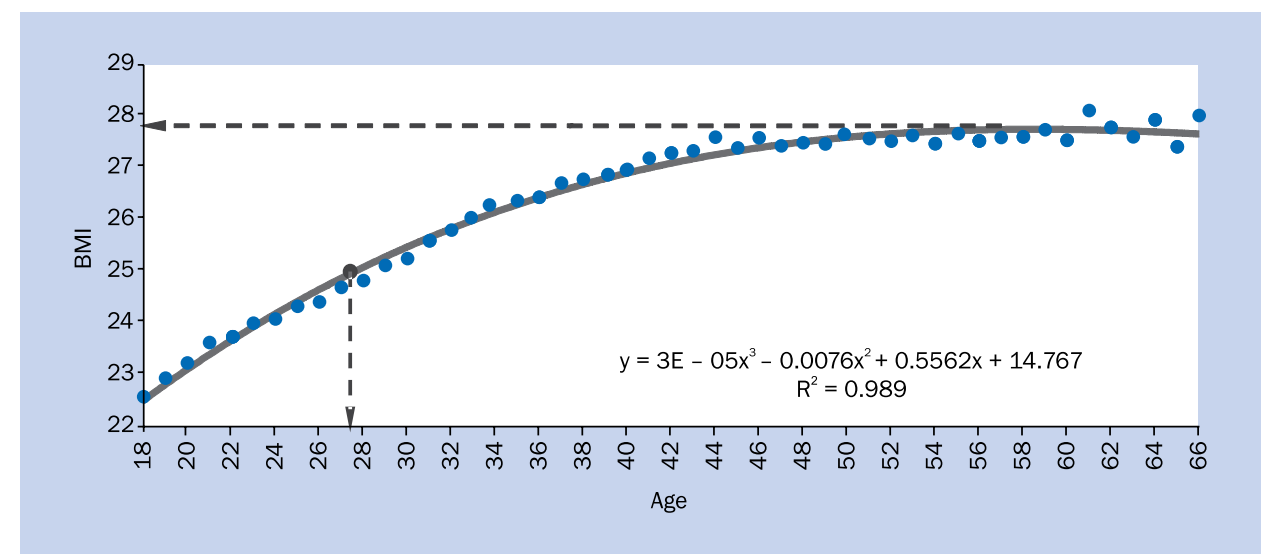

Figure 1. Regression curve of relationship between body mass index (BMI) and age

According to the analysis results, while Turkish male seafarers get older, their average weight values rise progressively and on average at the age of 44 years they reach a maximum of $82 \mathrm{~kg}$. Likewise, while Turkish male seafarers get older, their BMI values rise progressively. Moreover, it has been found that they reach $25 \mathrm{BMI}$ value, limit of overweight, at the age of 28 years, approximately. In addition, they reach maximum average $27.8 \mathrm{BMI}$ value at the age of 50 years.

\section{DISCUSSION}

This study is the first study showing the problem of excessive weight of Turkish seafarers. Also, the study shows that Turkish male seafarers began to gain excessive weight from the age of almost 28, and they reach the highest level of $\mathrm{BMI}$ value at their $50 \mathrm{~s}$.

Comparison of data on excessive weight among Turkish seafarers with results of other studies conducted in Turkish population showed undesirable pattern. The results of Health Survey Report 2013 presented by TSI [16] show that only $39 \%$ of Turkish men were found to be overweight. In this study $39.6 \%$ of Turkish male seafarers were found to be overweight, but rate of obesity among men in Turkish general population is higher than among Turkish male seafarers.
When compared the results to the study conducted by Hansen et al. [18], overweight percentage of Turkish male seafarers was higher than Danish male seafarers, according to $\mathrm{BMI}$ in all age groups. The prevalence of obesity among the Turkish male seafarers has been found to be at undesirable level. The obesity rate in Turkish seafarers between the age of 25-44 and 45-66 is higher than among Danish seafarers ( $3 \%$ and $8 \%$, respectively). Consequently, the percentage of obese and overweight Turkish male seafarers is higher than that of Danish male seafarers.

The limitation of the study is that the analysis includes only 4-year statistical data. It is believed that observation longer than 4 years gives more reliable results. Besides, the data used in this study was limited in terms of variable groups. A comparative evaluation can be done in terms of department, rank and sea experience as a further research. Additionally, it is proposed to investigate the effect of obesity on health and accident rate the on board a ship.

\section{CONCLUSIONS}

These results have shown that the activities which will provide awareness to Turkish seafarers and the ship operators about the dangers of obesity should be done. Also, convenient environments and time for physical exercise on board a ship must be provided for seafarers. In addition, 
eating habits, quality of food and health status of seafarers must be monitored on board a ship.

\section{ACKNOWLEDGEMENTS}

We would like to acknowledge the Republic of Turkey Ministry of Health Directorate General of Health for Border and Coastal Areas for their support and providing us with their statistical data for Medical Examination Report of Turkish Seafarers.

\section{REFERENCES}

1. World Health Organization, WHO (03.2013). Fact Sheet - Obesity and Overweight. http://www.who.int/mediacentre/factsheets/ fs311/en/index.html (01.12.2013).

2. Bağrlacık N, Onat $H$, İıhan $B$ et al. Obesity profile in Turkey. Int J Diabetes Metab 2009; 17: 5-8.

3. World Health Organization, WHO (2013). Health Topics, Obesity. http://www.who.int/topics/obesity/en/ (05.12.2013).

4. Health and Social Care Foundation (Turkey), HSCF (2010). Obesity and obesity policies in Europe and Turkey. http://www.ssyv.org.tr/ sdetay. .asp? $i d=1259 \&$ did=131 (05.12.2013).

5. The Ministry of Health (Turkey) (2013). What is overweight and obesity? http://www.beslenme.gov.tr/index.php?lang=en\&page=38 (05.12.2013).

6. Ozcirpici B, Coskun F, Sahnoz S, Ozgur S, Bozkurt Al. Obesity prevalence in Gaziantep, Turkey. Ind J Comm Med 2009; 34: 29-34.

7. Brunello G, D’Hombres B. Does body weight affect wages? Evidence from Europe. Econom Human Biol 2007; 5: 1-19.

8. Lash MM, Armstrong A. Impact of obesity on women's health. Fertility Sterility 2009; 91: 1712-1716.
9. Chen Z, Roy K, Carol A. Obesity prevention: the impact of local health departments. Health Services Res 2013; 48: 603-627.

10. Barkin SL, Heerman WJ, Warren MD, Rennhoff C. Millennials and the world of work: the impact of obesity on health and productivity. J Business Psychol 2010; 25: 239-245.

11. Hoeyer JL, Hansen HL. Obesity among Danish seafarers. Int Marit Health 2005; 56: 1-4.

12. Roberts SE, Nielsen D, Kotlowski A, Jaremin B. Fatal accident and injuries among merchant seafarers worldwide. Occup Med (Lond) 2014; 64: 259-266.

13. Bridger RS, Bennett Al. Age and BMI interact to determine work ability in seafarers. Occup Med (Lond) 2011; 61: 157-162.

14. World Health Organization. Obesity: Preventing and Managing the Global Epidemic, Geneva, 1997.

15. Katherine MF, Brian KK, Heather O, Barry IG. Association of allcause mortality with overweight and obesity using standard body mass index categories a systematic review and meta-analysis. JAMA 2013; 309: 71-82.

16. Turkish Statistical Institute, TSI (2013). Health Survey, 2012. Ankara: Turkish Statistical Institute Printing Division.

17. Hansen HL, Dahl S, Bertelsen B, Brix J. Life style, nutritional status and working conditions of Danish sailors. Travel Med Int 1994; 12:139-143.

18. Hansen $\mathrm{HL}$, Hjarnoe L, Jepsen JR. Obesity continues to be a major health risk for Danish seafarers and fishermen. Int Maritime Health 2011; 62: 98-103.

19. Nas S, ve Okşayan B. Çağımızın obezite sorunu: Dokuz Eylül Üniversitesi Denizcilik Fakültesinde obezite araştırması 5. Ulusal Denizcilik Kongresi, İstanbul, 2013.

20. ÖSYM. ÖSYS Tercih KIlavuzu, Ankara, 2014.

21. Howell RW. Height, weight and obesity in an industrial population. Occup Med (Lond) 1965; 15: 25-28. 